\title{
Phenotypic and genotypic characterization of Pseudomonas aeruginosa siderophores
}

\author{
Ashraf A. Kadry, Hisham A. Abbas, Marwa M. Ezz* \\ Department of Microbiology and Immunology, Faculty of Pharmacy, Zagazig \\ University- Zagazig- Egypt. \\ *Corresponding author e-mail: dr_mero_eg@yahoo.com
}

\begin{abstract}
Pseudomonas aeruginosa is an opportunistic human pathogen that causes many infections such as urinary tract, respiratory tract, burn infections in addition to septicemia. Iron $(\mathrm{Fe})$ is an essential element for the growth of most living microorganisms. Siderophores are iron chelating compounds produced by bacteria. Ps. aeruginosa produces two major siderophores; pyoverdine and pyochelin.

Ps. aeruginosa isolates were identified morphologically, biochemically and by culture characteristics. Siderophore production was assessed phenotypically by chrome azurol sulfonate (CAS) Shuttle assay and genotypically by PCR.

Siderophore production varied among the clinical isolates. High production was found in $63.33 \%$ of isolates. Intermediate production of siderophore was detected in $30 \%$, while $6.66 \%$ of isolates showed a low level of siderophores. Genotypic detection of genes responsible for the formation of siderophores and their receptors revealed the presence of $P v d S, P t x R$ and FpvA genes that are responsible for pyoverdine synthesis and its receptor formation in all isolates. Whereas pchG and FptA encoding pyochelin and its receptor were detected in $85.7 \%$ of isolates.
\end{abstract}

Siderophores are important iron chelators in Ps. aeruginosa. Substantial correlation was received from the genotypic and phenotypic investigations of siderophore production.

Key words: Ps. aeruginosa, Siderophores, pyoverdine, pyochelin

\section{INTRODUCTION}

Pseudomonas aeruginosa is frequently found as a part of the human microflora in healthy individuals. Ps. aeruginosa is an opportunistic pathogen for humans that is responsible for a wide range of diseases including infections of the urinary tract, respiratory tract, burn, and septicemia (Yang et al., 2011).

Iron $(\mathrm{Fe})$ is an essential element for the growth of most living microorganisms because it is used as a catalyst in enzymatic processes, oxygen metabolism, electron transfer, and synthesis of both DNA and RNA (Aguado-Santacruz et al., 2012).

Ps. aeruginosa produces two major siderophores; pyoverdine (Pvd) and pyochelin (Pch) (Schalk, 2008). Siderophores are low-molecular-weight chelating agents (200-2000 Dalton), characterized by an extremely high affinity for iron. They are able to deliver iron into bacteria via active transport systems (Boukhalfa and Crumbliss, 2002; Winkelmann, 2002).

Pyoverdine is a peptidic siderophore containing two hydroxamic groups and a fluorescent dihydroxyquinoline chromophore, which create a very efficient iron chelation center (Visca et al., 2007), while pyochelin is a salicylate-based siderophore with a lower affinity for iron (Brandel et al., 2012).

Both siderophores are actively transported across the outer membrane upon binding to specific receptors, namely, the FptA and FpvA outer membrane proteins for pyochelin and pyoverdine transport, respectively (Schalk and Guillon, 2013). 
Six genes encode the proteins required for pyoverdine synthesis have been identified in Pseudomonas aeruginosa PAO1 strain. Expression of these six genes requires a sigma factor $p v d S$ (Lamont and Martin, 2003).

The $p v c A B C D$ gene cluster from Pseudomonas aeruginosa has been linked to the biosynthesis of the pyoverdine chromophore. In addition, the $p v c$ gene cluster is positively regulated by $P t x R$, a LysR transcription factor (Clarke-Pearson and Brady, 2008).

Furtherly, the $p c h D C B A$ and $p c h E F$ genes responsible for biosynthesis of the pyochelin siderophore and its precursors salicylate and dihydroaeruginoate (Dha) are clustered with the $p c h R$ regulatory gene on the chromosome of Pseudomonas aeruginosa. The 4.6-kb region located downstream of the $p c h E F$ genes was found to contain three contiguous genes, $p c h G$, $p c h H$, and pchI, probably forming a pchEFGHI operon. The occurrence of mutation in $p c h G$ would abolish pyochelin formation, whereas mutations in $p c h H$ and pchI did not affect the amounts of salicylate, Dha, and pyochelin produced. So $p c h G$ is essential for pyochelin formation in Ps. aeruginosa (Reimmann et al., 2001).

The current study aims to detect siderophores produced by $P$ s. aeruginosa phenotypically and genotypically.

\section{MATERIALS and METHODS Bacterial strains}

A total of 120 clinical isolates of Pseudomonas aeruginosa were included in this study. They were recovered from 300 clinical specimens obtained from patients with wound infections, respiratory tract infections, urinary tract infections and burn infections admitted to Zagazig University Hospitals and AlAhrar hospital in Zagazig. A standard strain of Ps. aeruginosa (PAO1) was included in this study as a positive control for siderophore production.

\section{Identification of Pseudomonas aeruginosa}

The clinical isolates were identified morphologically by Gram stain and biochemically according to Koneman $\boldsymbol{e t}$ al (2006) including pyocyanin production and oxidase tests.

Quantitative assay for siderophore production by Chrome azurol sulfonate (CAS) - Shuttle assay

CAS solution was prepared by adding $7.5 \mathrm{ml}$ of $2 \mathrm{mM}$ CAS solution to $1.5 \mathrm{ml}$ of iron solution $\left(1 \mathrm{mM} \mathrm{FeCl} 3 \cdot 6 \mathrm{H}_{2} \mathrm{O}\right.$ in $10 \mathrm{mM} \mathrm{HCl}$ ) and $50 \mathrm{ml}$ hexadeclytrimethylammonium bromide (HDTMA) solution. CAS solution was mixed with $30 \mathrm{ml}$ piperazine-N,N-bis(2ethanesulfonic acid) (PIPES) buffer and the volume was brought to $100 \mathrm{ml}$ by distilled water.

Bacteria were grown in a minimal medium (M9 medium) at $37^{\circ} \mathrm{C}$ for 24 hours with shaking at $100 \mathrm{rpm}$. The cells were removed by centrifugation at 10000 rpm for 10 minutes at $4^{\circ} \mathrm{C}$ using Hermle cooling centrifuge, Germany. Aliquots of $0.5 \mathrm{ml}$ of the supernatant were mixed with aliquots of $0.5 \mathrm{ml}$ of CAS solution and $10 \mu 1$ shuttling solution (5-sulfosalicylic acid). After few minutes the orange color developed was assessed spectrophotometrically at $630 \mathrm{~nm}$ by using BioTek Synergy HT microplate reader, USA. The same procedure was performed also for reference solution (minimal medium + CAS dye + shuttle solution). Percentage of siderophore was estimated using the following formula:

$(\mathrm{Ar}-\mathrm{As}) / \mathrm{Ar} * 100=\%$ of siderophore

Where Ar is the Absorbance of reference (CAS assay solution + un-inoculated medium + shuttle solution) and As is the Absorbance of the sample (CAS assay solution + cell-free supernatant+ shuttle solution) (Schwyn and Neilands, 1987; Tank et al., 2012).

Genotypic detection of siderophores

The phenotypic detection of siderophores was confirmed genotypically among the Ps. aeruginosa isolates by PCR, 
where the genes encode synthesis of pyoverdine and pyochelin and their receptors were investigated.

The genomic DNA (gDNA) was extracted by picking a colony from agar plate using a sterile pipette tip and resuspended into $20 \mu \mathrm{l}$ of distilled water. The mixture was vortexed for $10 \mathrm{~s}$ then heated in water bath at $98{ }^{\circ} \mathrm{C}$ for $5 \mathrm{~min}$. The lysate was centrifuged and the resulting supernatant was collected, diluted with distilled water at a 1:3 dilution ratio, and subjected to PCR analysis (Reischl $\boldsymbol{e t}$ al., 2000). Each PCR mixture contained 10 $\mu \mathrm{l}$ of $\mathrm{MyTaq}^{\mathrm{TM}}$ master mix (Bioline

\section{ISSN (on-line) 2356_9786}

Reagents Limited, UK), $1.5 \mu \mathrm{l}$ of forward primer, $1.5 \mu \mathrm{l}$ of reverse primer, $2 \mu 1$ of gDNA template and nuclease free water to $20 \mu$ l. The primers used in this study are listed in (Table 1). Amplification reaction of each gene listed in (Table 2). The PCR was performed in Biometra $\mathrm{T}$-personal thermocycler (Goettingen, Germany). The PCR products as well as Gene-Ruler 100 bp and $1 \mathrm{~Kb}$ DNA Ladder (Thermoscientific Inc, USA) were separated on $1.5 \%$ agarose gel, stained with $2 \mu \mathrm{l}$ of $\mathrm{EtBr}$, and visualized by UV transilluminator and photographed.

Table1. Primer sequences and amplicon sizes of target genes.

\begin{tabular}{|c|c|c|c|}
\hline $\begin{array}{l}\text { Target } \\
\text { Genes }\end{array}$ & Primer sequence 5'-3' & $\begin{array}{l}\text { Amplicon } \\
\text { Size (bp) }\end{array}$ & Reference \\
\hline$p v d S-\mathrm{F}$ & 5'GCAGAATTCTCCGCAGCAAGGTGATTTCCATG-3` & 573 & (Leoni et \\
\hline$p v d S-\mathrm{R}$ & 5'CGCCAAGCTTAGCGGCGGGCGCTGAGATGGGT-3` & & $a l ., 1996)$ \\
\hline$p t x R-F$ & 5`- TCTAGACCCGTCCGGACCCACTTC-3` & 990 & (Stintzi et \\
\hline ptxR-R & 5-AAGCTTGCCCAGCCTCATTCGCTCTG-3` & & 1999) \\
\hline$f p v A-\mathrm{F}$ & 5`GAGCTCGAAGAGCAATCA CCCAT-3` & 2448 & (James et \\
\hline$f p v A-\mathrm{R}$ & 5-AAGCTTGGCGTTCTTTTTCGCA-3` & & al., 2005) \\
\hline$P \operatorname{ch} G-\mathrm{F}$ & 5`ATGCCAGAGGAGGCGAGCATATGAGCGACGTTCG & 1047 & (Reimma \\
\hline PchGR & $\begin{array}{l}\text { TTCCG-3` } \\
\text { 5`AGCAGGCGCCACAGCACCGCTCGAGCGAGGCTTG } \\
\text { CTCC-3` }\end{array}$ & & $\begin{array}{c}\text { nn et al., } \\
\text { 2001) }\end{array}$ \\
\hline$f p t A-\mathrm{F}$ & 5-GTGACGAGCTCAATACGGGCCG-3` & 2163 & (Visser et \\
\hline fptA-R & 5-CCCCAAGCTTGACGCCATCAGA-3` & & al., 2004) \\
\hline
\end{tabular}

Table 2. Amplification reaction cycles of genes

\begin{tabular}{|c|c|c|c|c|c|c|}
\hline \multirow[t]{2}{*}{ Thermal Step } & \multicolumn{5}{|c|}{ Gene tested } & \multirow{2}{*}{$\begin{array}{c}\text { Number of } \\
\text { cycles }\end{array}$} \\
\hline & $P v d S$ & PtxR & $F p v A$ & $P \operatorname{ch} G$ & FptA & \\
\hline $\begin{array}{l}\text { Initial } \\
\text { denaturation }\end{array}$ & $\begin{array}{l}95^{\circ} \mathrm{C} \text { for } \\
3 \mathrm{~min}\end{array}$ & $\begin{array}{l}95^{\circ} \mathrm{C} \text { for } \\
3 \mathrm{~min}\end{array}$ & $\begin{array}{l}95^{\circ} \mathrm{C} \text { for } \\
3 \mathrm{~min}\end{array}$ & $\begin{array}{l}95^{\circ} \mathrm{C} \text { for } \\
3 \mathrm{~min}\end{array}$ & $\begin{array}{l}95^{\circ} \mathrm{C} \text { for } \\
3 \mathrm{~min}\end{array}$ & 1 \\
\hline Denaturation & $\begin{array}{c}95^{\circ} \mathrm{C} \text { for } \\
20 \mathrm{sec}\end{array}$ & $\begin{array}{c}95^{\circ} \mathrm{C} \text { for } \\
30 \mathrm{sec}\end{array}$ & $\begin{array}{c}95^{\circ} \mathrm{C} \text { for } \\
30 \mathrm{sec}\end{array}$ & $\begin{array}{c}95^{\circ} \mathrm{C} \text { for } \\
30 \mathrm{sec}\end{array}$ & $\begin{array}{c}95^{\circ} \mathrm{C} \text { for } \\
30 \mathrm{sec}\end{array}$ & \\
\hline Annealing & $\begin{array}{c}60^{\circ} \mathrm{C} \text { for } \\
30 \mathrm{sec}\end{array}$ & $\begin{array}{c}50^{\circ} \mathrm{C} \text { for } \\
50 \mathrm{sec}\end{array}$ & $\begin{array}{c}40^{\circ} \mathrm{C} \text { for } \\
30 \mathrm{sec}\end{array}$ & $\begin{array}{c}46^{\circ} \mathrm{C} \text { for } \\
30 \mathrm{sec}\end{array}$ & $\begin{array}{c}56^{\circ} \mathrm{C} \text { for } \\
30 \mathrm{sec}\end{array}$ & 30 \\
\hline Elongation & $\begin{array}{c}74^{\circ} \mathrm{C} \text { for } \\
1 \mathrm{~min}\end{array}$ & $\begin{array}{c}72^{\circ} \mathrm{C} \text { for } \\
1 \mathrm{~min}\end{array}$ & $\begin{array}{l}72^{\circ} \mathrm{C} \text { for } \\
2 \mathrm{~min}\end{array}$ & $\begin{array}{c}72^{\circ} \mathrm{C} \text { for } \\
1 \mathrm{~min}\end{array}$ & $\begin{array}{l}72^{\circ} \mathrm{C} \text { for } \\
2 \mathrm{~min}\end{array}$ & \\
\hline $\begin{array}{l}\text { Final } \\
\text { elongation }\end{array}$ & $\begin{array}{c}72^{\circ} \mathrm{C} \text { for } \\
5 \mathrm{~min}\end{array}$ & $\begin{array}{l}72^{\circ} \mathrm{C} \text { for } \\
7 \mathrm{~min}\end{array}$ & $\begin{array}{l}72^{\circ} \mathrm{C} \text { for } \\
7 \mathrm{~min}\end{array}$ & $\begin{array}{l}72^{\circ} \mathrm{C} \text { for } \\
7 \mathrm{~min}\end{array}$ & $\begin{array}{c}72^{\circ} \mathrm{C} \text { for } \\
7 \mathrm{~min}\end{array}$ & 1 \\
\hline
\end{tabular}

\section{Electrophoresis and visualization of} PCR amplicons

The running chamber was assembled on a horizontal section of the bench. Sufficient electrophoresis tris acetate EDTA buffer (1X TAE) was added to fill the electrophoresis tank and to cast the gel. The agarose solution (1.5\%) was 
prepared in TAE buffer (1X) and heated in a microwave oven to dissolve the agarose. When the molten gel has cooled, ethidium bromide (EtBr) was added to a final concentration of $0.2 \mu \mathrm{g} / \mathrm{ml}$. The gel solution was mixed thoroughly by gentle swirling. The molten agarose was poured into the running chamber with an appropriate comb and left to solidify (3045 minutes). The comb was removed after flooding the gel with TAE buffer. The gel was mounted in the electrophoresis tank. Just enough electrophoresis buffer was added to cover the gel to a depth of $1 \mathrm{~mm}$. Each DNA sample $(10 \mu \mathrm{l})$ was loaded carefully in separate well using micropipette then was separated according to its molecular size by electrophoresis at $4 \mathrm{v} / \mathrm{cm}$. The master mix used is supplemented with two tracking dyes that allow for direct loading of the PCR product on a gel. The electrophoresis power was shut off after the tracking dyes band reached to nearly the end of the gel length. The gel was visualized on UV transilluminator and photographed (Sambrook and Russell, 2001).

\section{RESULTS \\ Identification of Pseudomonas aeruginosa}

Pseudomonas aeruginosa isolates were identified as Gram-negative rods. They produced pyocyanin and fluorescein on cetrimide agar and they were motile, oxidase positive and grew at $42^{\circ} \mathrm{C}$.

\section{Phenotypic determination of siderophore production}

In order to screen for siderophore production, the method of CAS- Shuttle assay was used. The presented results were the average of siderophore percentage from 4 experiments. The tested isolates showed variable abilities in siderophore production (Table 3 and Fig1). High siderophore production was suggested (if the percentage is $\geq 60 \%$ ), intermediate (if the percentage is $\leq 50 \%$ and $\geq 30 \%$ ) and low (if the percentage is $\leq 29 \%$ ). PAO1 showed $60 \%$ siderophore production. High siderophore production was observed in $63.33 \%$ of total isolates. Intermediate production of siderophore was detected in $30 \%$ while $6.66 \%$ of total isolates showed low siderophore production.

Table 3. Siderophore production by $P$ s. aeruginosa isolates.

\begin{tabular}{cc}
\hline $\begin{array}{c}\text { Percentage }(\%) \text { of } \\
\text { siderophore }\end{array}$ & $\begin{array}{c}\text { Number of } \\
\text { isolates }\end{array}$ \\
\hline $60 \%$ & PAO1 \\
\hline$\geq 80 \%$ & 6 \\
$\leq 79 \%-70 \%$ & 43 \\
$\leq 69 \%-60 \%$ & 27 \\
$\leq 59 \%-50 \%$ & 17 \\
$\leq 49 \%-40 \%$ & 12 \\
$\leq 39 \%-30 \%$ & 7 \\
$\leq 29 \%-20 \%$ & 6 \\
$\leq 19 \%-10 \%$ & 1 \\
$\leq 9 \%-1 \%$ & 1 \\
\hline
\end{tabular}

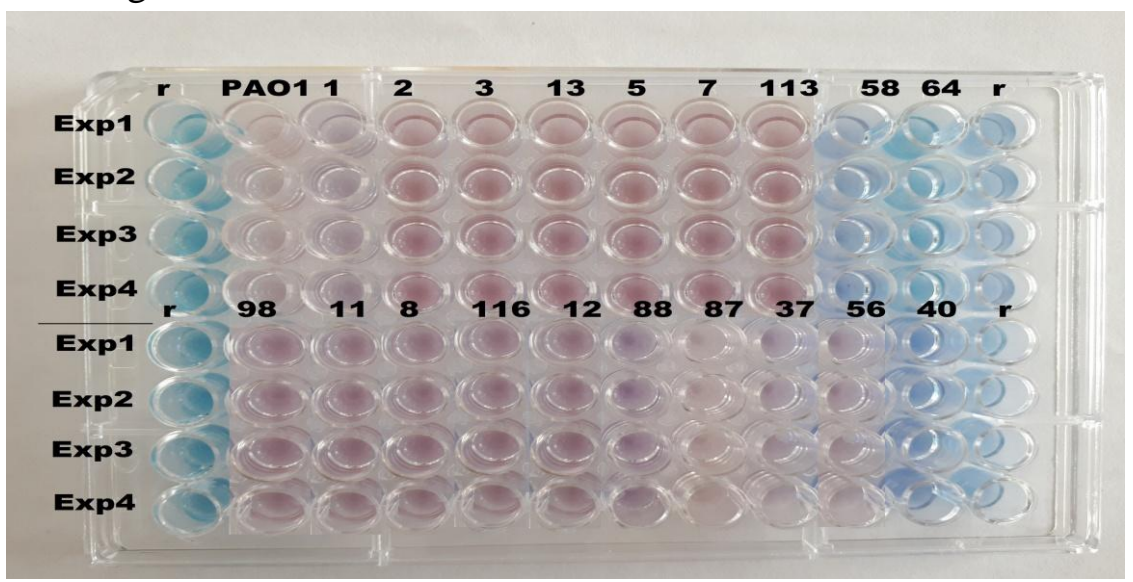

Fig 1. siderophore detection by CAS shuttle assay reference (CAS assay solution + uninoculated medium + shuttle solution) 
Zagazig J. Pharm. Sci. June, 2018

Vol. 27, Issue 1, pp. 22- 30

\section{Genotypic detection of siderophores}

To investigate the presence of siderophore encoding genes of 56 isolates which they were selected to represent the different percentage levels of siderophore production.

Upon detection of pyoverdine and its receptor, it was found that PAO1 strain
ISSN 1110-5089

ISSN (on-line) 2356_9786

and all clinical isolates gave a single band at $573 \mathrm{bp}$ match to $P v d S$ gene (Figure 2A). For PtxR gene, PAO1 strain and all clinical isolate gave a single band at 990 bp (Figure 2-B). For amplification of $f p v A$ gene encoding outermembrane receptor, PAOI strain and all clinical isolate gave single band at 2448 bp (Figure 2-C).

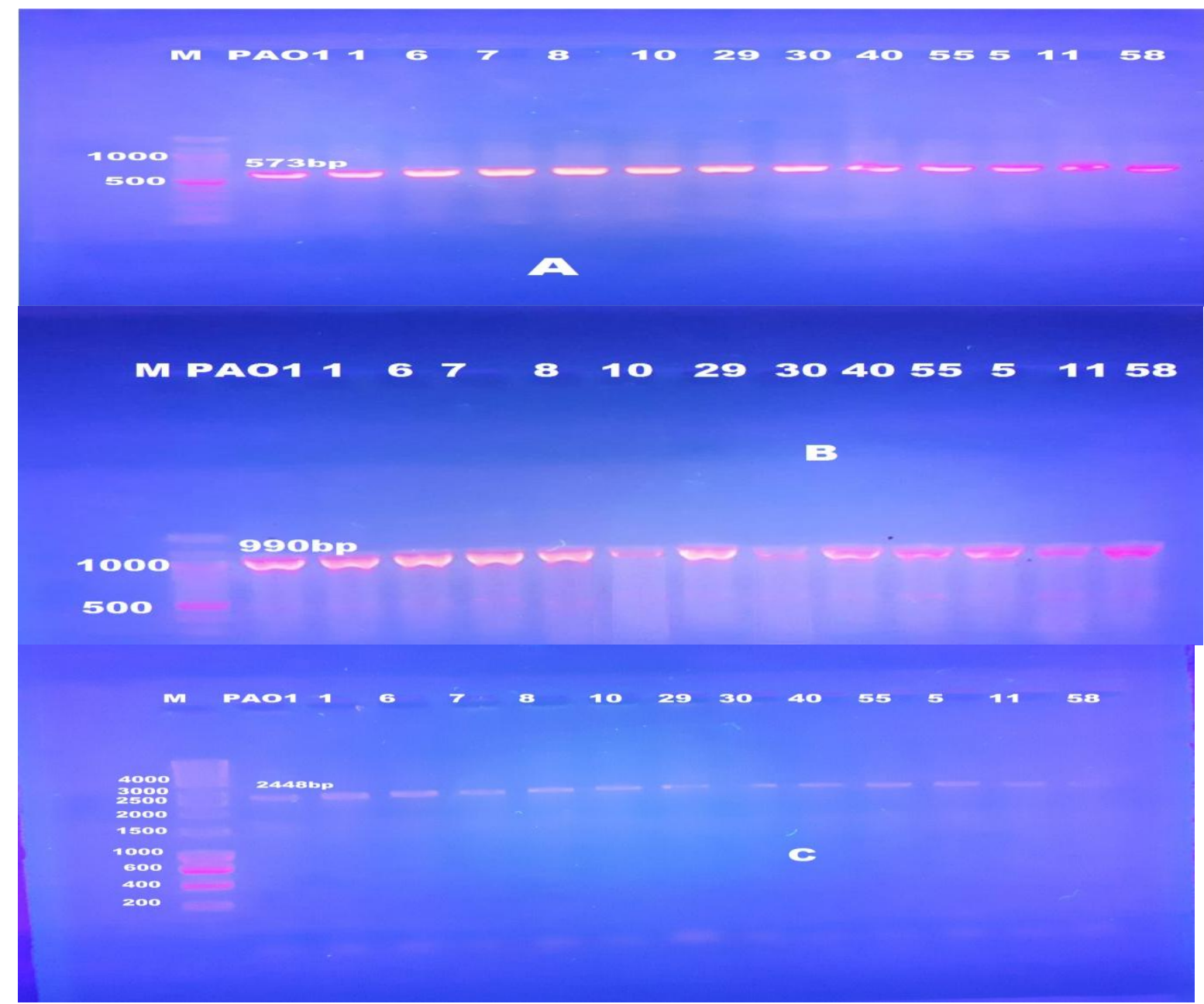

Fig2. Gel electrophoresis of PCR products for detection of pyoverdine genes and its receptor of representing isolates. Fig 2A. detection of $P v d S$ gene in all isolates gave a single band at $573 \mathrm{bp}$, Fig2B. detection of PtxR gene in all isolates gave a single band at 990bp, Fig2C.detection of $f p v A$ gene in all isolates gave a single band at $2448 \mathrm{bp}$. bp: base pair. M: marker.

Upon detection of pyochelin and its receptor, it was found that a single band of expected product size of $1047 \mathrm{bp}$ confirmed the presence of $P \operatorname{ch} G$ gene in $85.7 \%$ of isolates and in PAO1 strain
(Figure 3-A). In case of fptA receptor gene encoding outermembrane receptor, PAO1 strain and $85.7 \%$ of isolates gave a single band at 2163bp (Figure 3-B). 


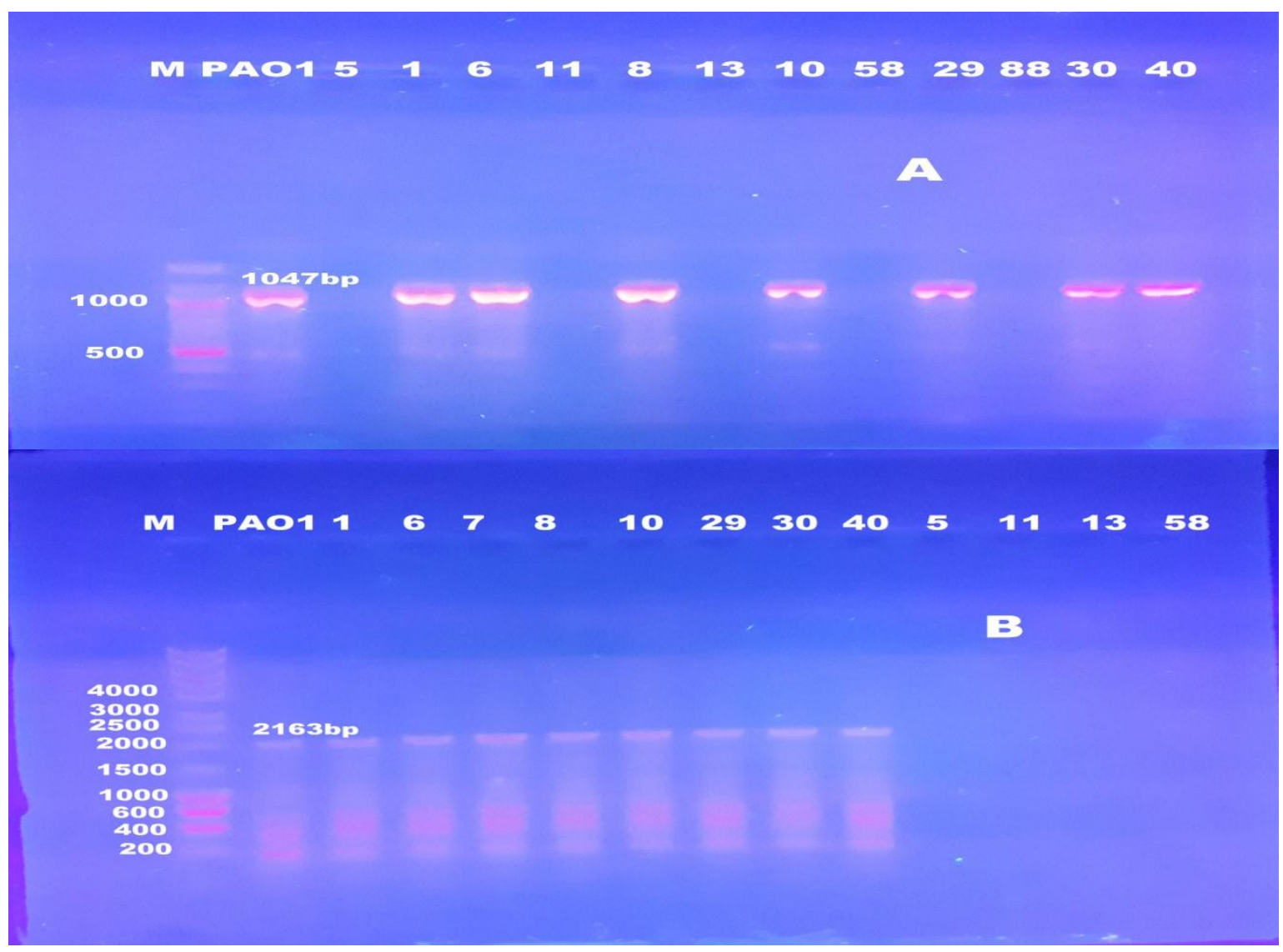

Fig 3. Gel electrophoresis of PCR products for detection of pyochelin gene and its receptor. Fig 3A. detection of $P c h G$ gene in PAO1 and clinical isolates gave a single band at 1047bp, Fig3B. detection of fptA gene in PAO1 and clinical isolates gave a single band at 2163bp.

\section{DISCUSSION}

Ps. aeruginosa is a Gram-negative bacteria frequently found in soil, marine habitats, plants, animals, and humans (Filiatrault et al., 2006). It is responsible for $10-15 \%$ of the nosocomial infections worldwide (Strateva and Yordanov, 2009).

This study was performed to detect and quantify siderophores produced by $P S$. aeruginosa isolates. Moreover, for genotypic investigation of pyoverdine and pyochelin, the genes amplified by PCR were detected.

The CAS assay is the universal assay for siderophore detection and is based on a siderophore's high affinity for ferric iron (Louden et al., 2011). In this study, Ps. aeruginosa isolates showed variable siderophore production by CASShuttle assay. The production of sideophore was detected by the change in the colour of CAS from blue to orange (yellow brown). When comparing the average percentage of siderophore production between isolates according to their sources, the maximum production is $72.17 \%$ were found in isolates from urinary tract infections, followed by those recovered from respiratory tract infections where the production was $71.45 \%$, followed by wound infections isolates where the production was $55.48 \%$ and the least siderophore level was found in burn infections isolates where average percentage of production was $52.20 \%$. These results were in consistent with that reported by Ali and Vidhale (2011) who estimated the amount of siderophore produced by different $P$ s. aeruginosa isolates. They found that amount of siderophore production varied in clinical isolates and the maximum siderophore 
production was found in strains isolated from urinary tract infections, followed by wound and burn infection, respectively.

The presence of $P v d S, P t x R$ and $f p v A$ genes in all clinical isolates confirmed their importance in pyoverdine and its receptor formation in Pseudomonas aeruginosa (Lamont and Martin, 2003; Stintzi et al., 1999). For pyochelin production, detection of $P c h G$ and $f p t A$ genes were selected for investigatin because they are essential for pyochelin synthesis and its specific receptor (Reimmann et al., 2001; Visser et al., 2004).

Our data show that pyoverdine genes were detected in all clinical isolates, while pyochelin genes were detected in only $85.7 \%$ of isolates, moreover, some of isolates which have pyoverdine genes and lack pyochelin genes showed high siderophore production. Collectively, the above findings may explain that pyoverdine has the main role in iron chelation while pyochelin has a secondary role in iron uptake.

\section{Conclusion}

Siderophores have a vital role in iron uptake in Ps. aeruginosa. Pyoverdine has a higher affinity for iron than pyochelin confirmed by phenotypic and genotypic detection.

\section{REFERENCES}

Aguado-Santacruz, G. A., MorenoGomez, B., Jimenez-Francisco, B., Garcia-Moya, E. and Preciado-Ortiz, R. E. (2012). Impact of the microbial siderophores and phytosiderophores on the iron assimilation by plants: a synthesis. Revista Fitotecnia Mexicana, 35(1), 9-21.

Ali, S. S. and Vidhale, N. (2011). Evaluation of siderophore produced by different clinical isolate Pseudomonas aeruginosa. International Journal of Microbiology Research, 3(3), 131.
Boukhalfa, H., and Crumbliss, A. L. (2002). Chemical aspects of siderophore mediated iron transport. Biometals, 15(4), 325339.

Brandel, J., Humbert, N., Elhabiri, M., Schalk, I. J., Mislin, G. L. and Albrecht-Gary, A.-M. (2012). Pyochelin, a siderophore of Pseudomonas aeruginosa: physicochemical characterization of the iron (III), copper (II) and zinc (II) complexes. Dalton transactions, 41(9), 2820-2834.

Clarke-Pearson, M. F. and Brady, S. F. (2008). Paerucumarin, a new metabolite produced by the $p v c$ gene cluster from Pseudomonas aeruginosa. Journal of bacteriology, 190(20), 6927-6930.

Filiatrault, M. J., Picardo, K. F., Ngai, H., Passador, L. and Iglewski, B. H. (2006). Identification of Pseudomonas aeruginosa genes involved in virulence and anaerobic growth. Infection and immunity, 74(7), 4237-4245.

James, H. E., Beare, P. A., Martin, L. W., and Lamont, I. L. (2005). Mutational analysis of a bifunctional ferrisiderophore receptor and signal-transducing protein from Pseudomonas aeruginosa. Journal of bacteriology, 187(13), 4514-4520.

Koneman, E., Winn, W. C., Allen, S., Janda, W., Procop, G., Schreckenberger, P. and Woods, G. (2006). Koneman's color atlas and textbook of diagnostic microbiology: Lippincott williams $\&$ wilkins.

Lamont, I. L. and Martin, L. W. (2003). Identification and characterization of novel pyoverdine synthesis genes in Pseudomonas aeruginosa. Microbiology, 149(4), 833-842.

Leoni, L., Ciervo, A., Orsi, N., and Visca, P. (1996). Iron-regulated transcription of the $p v d A$ gene in 
Pseudomonas aeruginosa: effect of Fur and $P v d S$ on promoter activity. Journal of bacteriology, 178(8), 2299-2313.

Louden, B. C., Haarmann, D. and Lynne, A. M. (2011). Use of blue agar CAS assay for siderophore detection. Journal of microbiology \& biology education: JMBE, 12(1), 51.

Reimmann, C., Patel, H. M., Serino, L., Barone, M., Walsh, C. T. and Haas, D. (2001). Essential PchGdependent reduction in pyochelin biosynthesis of Pseudomonas aeruginosa. Journal of bacteriology, 183(3), 813-820.

Reischl, U., Linde, H.-J., Metz, M., Leppmeier, B. andLehn, $\mathrm{N}$. (2000). Rapid identification of methicillin-resistant

Staphylococcus aureus and simultaneous species confirmation using real-time fluorescence PCR. Journal of Clinical Microbiology, 38(6), 2429-2433.

Sambrook, J. and Russell, D. W. (2001). Molecular cloning: a laboratory manual 3rd edition. ColdspringHarbour Laboratory Press, UK.

Schalk, I. J. (2008). Metal trafficking via siderophores in Gram-negative bacteria: specificities and characteristics of the pyoverdine pathway. Journal of inorganic biochemistry, 102(5-6), 1159-1169.

Schalk, I. J. and Guillon, L. (2013). Fate of ferrisiderophores after import across bacterial outer membranes: different iron release strategies are observed in the cytoplasm or periplasm depending on the siderophore pathways. Amino Acids, 44(5), 1267-1277.

Schwyn, B. and Neilands, J. (1987). Universal chemical assay for the detection and determination of siderophores. Analytical biochemistry, 160(1), 47-56.

Stintzi, A., Johnson, Z., Stonehouse, M., Ochsner, U., Meyer, J.-M., Vasil, M. L. and Poole, K. (1999). The pvc Gene Cluster of Pseudomonas aeruginosa: Role in Synthesis of the Pyoverdine Chromophore and Regulation by $P t x R$ and $P v d S$. Journal of bacteriology, 181(13), 4118-4124.

Strateva, T. and Yordanov, D. (2009). Pseudomonas aeruginosa-a phenomenon of bacterial resistance. Journal of medical microbiology, 58(9), 1133-1148.

Tank, N., Rajendran, N., Patel, B. and Saraf, M. (2012). Evaluation and biochemical characterization of a distinctive pyoverdin from a Pseudomonas isolated from chickpea rhizosphere. Brazilian Journal of Microbiology, 43(2), 639-648.

Visca, P., Imperi, F. and Lamont, I. L. (2007). Pyoverdine siderophores: from biogenesis to biosignificance. Trends in microbiology, 15(1), 2230.

Visser, M., Majumdar, S., Hani, E. and Sokol, P. (2004). Importance of the ornibactin and pyochelin siderophore transport systems in Burkholderia cenocepacia lung infections. Infection and immunity, 72(5), 2850-2857.

Winkelmann, G. (2002). Microbial siderophore-mediated transport: Portland Press Limited.

Yang, L., Jelsbak, L., Marvig, R. L., Damkiær, S., Workman, C. T., Rau, M. H., Hansen, S. K., Folkesson, A., Johansen, H. K. and Ciofu, O. (2011). Evolutionary dynamics of bacteria in a human host environment. Proceedings of the National Academy of Sciences, 108(18), 7481-7486. 


\section{الكشف عن السيداروفورات من عزلات السودوموناس اريجينوزا بواسطة الطرق النمطية و الجينيه.}



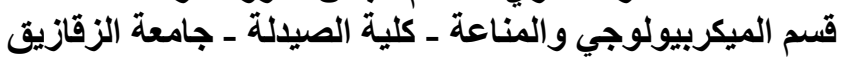

السودوموناس اريجينوزا بكتيريا تسبب العديد من الأمراض المعديه للانسان مثل المسالك البولية ، و الجهاز

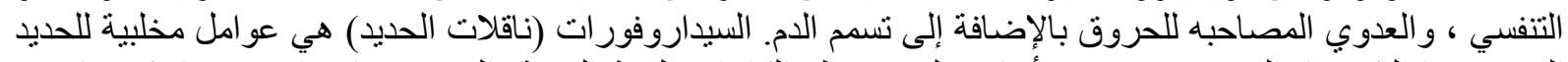
التي تتنجها البكتيريا. الحديد هو عنصر أساسي لنمو معظم الكائنات الحية الدقيقة. السودوموناس أريجينوز الكتينيريا تنتج

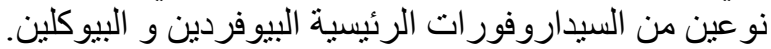

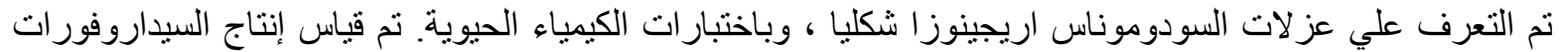

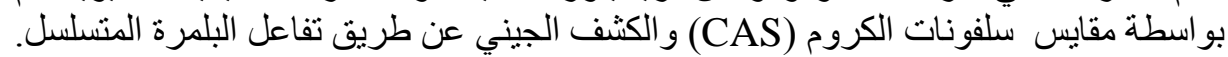



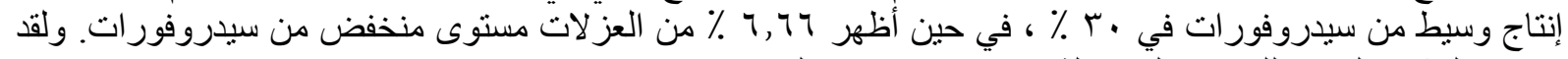

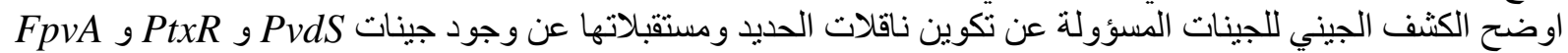

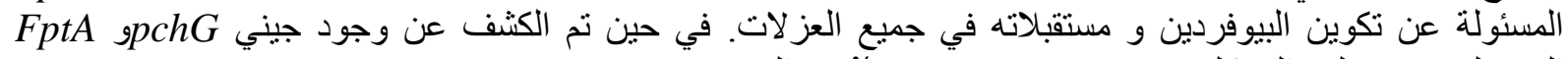

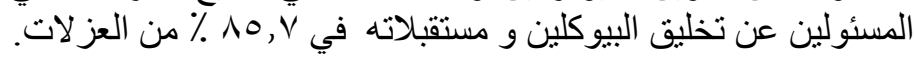

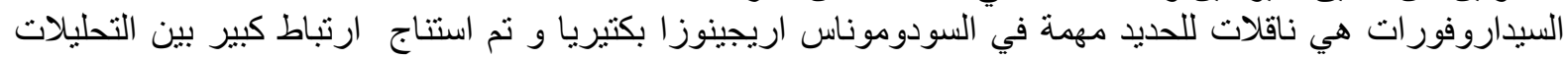
الور اثية و النمطيه في إنتاج السيداروفورات 